\title{
Circuit
}

Musiques contemporaines

\section{Klas Torstensson in Conversation Klas Torstensson en Conversation}

\section{Jonathan Goldman}

Volume 14, numéro 2, 2004

Montréal/Nouvelles Musiques

URI : https://id.erudit.org/iderudit/902312ar

DOI : https://doi.org/10.7202/902312ar

Aller au sommaire du numéro

Éditeur(s)

Les Presses de l'Université de Montréal

ISSN

1183-1693 (imprimé)

1488-9692 (numérique)

Découvrir la revue

Citer ce document

Goldman, J. (2004). Klas Torstensson in Conversation. Circuit, 14(2), 49-52. https://doi.org/10.7202/902312ar

\section{Résumé de l'article}

Pendant son séjour en tant que compositeur invité au festival MNM, Klas Torstensson discute avec Jonathan Goldman de ses conceptions musicales. A la suite de l'exécution de son monumental triptyque Licks and Brains,

Torstensson exprime son avis sur le minimalisme néerlandais, sur les modes d'interaction qu'il vise entre compositeur et interprète, sur les concepts de réseau et de fragmentation comme techniques de composition et sur le rôle primordial de l'intuition dans l'élaboration du discours musical. d'utilisation que vous pouvez consulter en ligne.

https://apropos.erudit.org/fr/usagers/politique-dutilisation/ 


\title{
Klas Torstensson in Conversation
}

\author{
Jonathan Goldman
}

Klas Torstensson (b. 1951 Nässjö, Sweden) studied composition and music theory at the Ingesunds Musikhögskola, musicology at the University of Gothenburg, and electronic/computer-generated music at the Institute for Sonology in Utrecht. Since 1973 he has lived and worked in the Netherlands. His works have been performed by a number of orchestras and ensembles throughout the world.

In 1991 he received the Mathijs Vermeulenpriijs, the most prestigious award for composition in the Netherlands, and in the same year began composing Urban Songs, a commission from IRCAM for soprano Charlotte Riedijk, the Ensemble Intercontemporain, and electronics. Between 1994 and 1999, Klas Torstensson directed his energy toward the composition of an opera entitled The Expedition for soloists, full orchestra and live electronics. In March 1999, he was guest composer at the Stockholm New Music Festival, along with Mauricio Kagel and György Kurtág, an event at which several of his most recent works were performed. In November of the same year, the Kungliga Musikaliska Akademien (Royal Academy of Music) in Stockholm bestowed on him the Stora Christ Johnson Priset, the most important Swedish award for composition.

Since 1999 he has been working on the cycle Lantern Lectures, a joint commission from Montreal's Nouvel Ensemble Moderne, ASKO Ensemble (Amsterdam), KammarensembleN (Stockholm), and Klangforum Wien. Torstensson gave lectures at festivals such as Stockholm New Music Festival, Ultima Festival in Norway, Holland Festival, Amsterdam, as well as at a number of conservatories and universities. In the summer of 2001 Torstensson was guest composer/lecturer at the Time of Music Festival in Viitasaari, Finland. Most of his compositions have been released on CD, most recently the opera The Expedition, Peter Eötvös conducting the Netherlands Radio Philharmonic Orchestra (Composers' Voice CV100).

\section{March 8, 2003, Montreal, Quebec}

Jonathan Goldman - Klas Torstensson, whenever I interview composers, I like to give them my impressions of their style, to offer a deliberately naive opinion of what I think they're doing or they're about, in order to get them to react to what I say, which is laced, as most judgments are, by a certain amount of prejudice.

Klas Torstensson - It's very important to be convinced of a few good prejudices, in order to get through life! [laughs] 
JG - At first I thought, from listening to Licks and Brains and looking at the score, that you were a 'maximalist' composer living among minimalists, in your adopted country of 30 years, Holland. But on second thought, I think that you're actually a minimalist and a maximalist at the same time. In your presentation yesterday, in speaking about Licks and Brains, you said that the two essential elements of that piece are on the one hand, the main notes, what you called the 'network', which features a threenote motif, and on the other, all the (many) little notes in between, which you call the 'slag'. I think that the network is minimalist and that the slag is maximalist.

KT - I'm perfectly comfortable with that formulation. I dislike minimalism in general, but I still appreciate some of its qualities: its groundedness, its earthiness, as well as things like some of its instrumentations and its use of bass-lines. I incorporate some of these elements in my work, like the presence of bass-lines, and even the use of bass guitar [in Licks and Brains II]. Dutch music today is still dominated by the socalled 'Hague-school', the pupils of Louis Andriessen, and remains profoundly touched by minimalism.

JG - This idea of a 'network', which you compared in your lecture to the posts of a fence, make me think of Boulez's notion of 'signals'; Boulez likens these to milestones which help the listener navigate through the work, to grasp the work's contour.

KT - In my work, they are not so much 'signals' as they are 'triggers', which is the term I often use, because they cause something to happen: they incite one group to react with another. I call this the 'reset' point, which is a term that Lovis Andriessen borrowed from me. You know, in Holland, some people consider me to be the bad conscience of Andriessen! [laughs].

JG - The 'reset' point? What is that?

$\mathrm{KT}$ - For me, variation is one of the most important compositional techniques. The point at which a new variation starts is the 'reset' point. It is the point at which we recommence with a (relatively) blank slate. It's like chopping wood, which is incidentally one of my favourite hobbies when I stay at my summer house. You chop something, and it results in two halves; then you must find ways to put them back together again. You find this in Licks and Brains: I develop the material until I come to an end point [hums passage of Licks and Brains in which all the players play repeated-note ostinati], then I start again. I often use sociological concepts in describing and constructing my music. You have, for example, two musics which compete with each other, which are in an antagonistic relationship. There is a winner and a loser; one is defeated, and is possibly eaten up by the other.

JG - Which of course is an old tradition in classical music, the concerto-concept being based on antagonism...

KT - Yes, I was more interested in this in the era of Licks and Brains [1987-1988]; today I use the notion of conflict to a much lesser extent.

JG - You have said that your music was not a music of fragments, but of fragmentation. What's the difference? 
KT - A music of fragments begins with fragmentary ideas, and builds the piece out of them. With me, they start whole, and get broken down into fragments. In my music I rarely begin with fragments, because I am interested in physical effects. In nature, things get broken down, not the opposite.

JG - Like the law of entropy according to which you can spill your drink, but it is infinitely rarer for spilled drops to all fall back into an empty glass...

KT - True, but this does not hold in electronic music, where you can play the tape backwards or forwards!

JG - Getting back to sociological concepts, this is an area which you know well, having studied and taught the sociology and the anthropology of music in your native Sweden. What other concepts do you incorporate into your music?

KT - In Weerwerk, I was interested in all of the possible outcomes of interactions between opposite forces. Two forces can approach each other but miss, in which case nothing happens. They can also collide, in which case they can fuse and form one music, or explode into ten different musics. Then I formalized all the possible outcomes, and used this to write the piece.

JG - You said that up to the era of Licks and Brains, your music was very vigorous and athletic: you worked in different shades of grey, as you put it. Then, and this change you attribute to becoming a father, your music started incorporating different colours, which explains the luxuriousness of your opera The Expedition [19941999]. What music do you think you'll write in ten years?

KT - Even better music! [laughs] I wouldn't want to limit myself, and I try not think more than two pieces ahead. Each piece I write is a commentary on the one which precedes it, and I often try to incorporate the old piece into the new one [like the sax quartet Licks and Brains I which is incorporated into Licks and Brains II for sax quartet and orchestra]. I never try to consciously change my style; in fact, I never think in terms of style. At the same time, I am aware of tradition, and the fact that my music reflects the tradition of which I am a product. That's why, for example, it's no coincidence that I used bass guitar and percussion in Licks and Brains: it reflects my youth in Sweden. When I studied at the conservatory in Sweden, I was the only composition student, and in fact, I wasn't even studying composition, because there was no such program at the time. I was a clarinet student. Students there would play my music every week; that is why I believe it's so important to be in touch with the musicians, and to understand how they play.

JG - Is that why you use jazz music in Licks and Brains, not only in the title word 'licks', but in the musical style itself?

$\mathrm{KT}$ - Yes, of course. I am always involved in a collaboration with the musicians for whom I write music. I always take inventory of the musicians' specific backgrounds: I go to their concerts, listen to their music; most saxophone players come from a jazz background, which is true of the Netherlands Saxophone Quartet [for whom the piece was originally composed]. I try to take into account the identities of the players, and 
to have the music reflect these identities; at the risk of sounding arrogant, l even hope to enrich their musical horizons sometimes, to take them further. For example, I wrote music for two groups which were founded by Louis Andriessen: Hoketus and De Volharding. In the case of Hoketus, I wrote the last piece they ever played, because it needed to be conducted. They had never played with a conductor, and they ended up disbanding after that! Similarly, with De Volharding, after playing my piece, they started using a conductor. So their orientation was changed. This shows my relationship with ensembles: they are like animals which must be made to evolve, to alter their orientation. I hate repetition... It's important to 'feed' the musicians, but it's also important to give them something back.

JG - It sometimes seems to me as if there were a kind of modern composer who lives with the recognition of a problem - in society, or in the times -, which amounts to what you might call an 'Adorno complex': there is no more music to be written, the work-concept itself is repudiated, the tradition is severed, the goals of the musical modernists are dubious, to the point of casting doubt on musical teleology itself. In your opera, The Expedition, this is perhaps symbolized in the doomed voyage of those Swedish explorers who tried to reach the North Pole by hydrogen balloon, and ended up in the ice: their plight, from a modern perspective, seems almost too absurd to be tragic. Must the composer of today be conscious of a 'problem', of a crisis?

KT - A composer should see problems, and if he doesn't, he should 'problematize' things. You should always begin a piece by asking yourself 'what problems am I trying to solve with this piece?', and if you can't answer that question, maybe there's no need to compose it at all. There are two key ingredients for writing music: passion and necessity. Necessity is the problem which needs to be solved; passion is what drives you to write the piece at all. Once you have chosen the musicians, the ensemble, then the music comes. You set premises, and then you write: that is where the passion comes in; otherwise, there's no motivation. Otherwise, you might as well leave it aside. Of course, you have to make compromises, with institutions, and so on, but passion is still the most important element.

JG - Boulez, writing about a composer's development, describes three stages. The first stage involves consciously absorbing the influences of one's chosen 'masters', of the 'heritage' as he calls it; in the last phase, this 'héritage' becomes a second nature, and the writing becomes freer.

KT - That's why I trust my intuition more in my work now. I write much more freely than I used to, and sometimes, I'm not even aware of the influences, or the connections with the past. Once, after hearing one of my pieces, someone said to me 'that's a quotation from the Sacre [du printemps]'. He was right, but I hadn't even realized it. I think Boulez forgets one stage though: the rebellious stage, which is very important for me, but also for him, I think, like his saying that opera is dead. I'm a child of the sixties, and had a very rebellious stage. At that time, the idea of writing an opera, with acts, arias, overtures and even singing, would have been unthinkable for me. 